\title{
Comparison of $20 \%$ sulfur hexafluoride with air for intraocular tamponade in Descemet membrane endothelial keratoplasty (DMEK)
}

\author{
Comparação de hexafluoreto de enxofre a $20 \%$ com ar para tamponamento intraocular na \\ ceratoplastia endotelial de membrana Descemet (DMEK)
}

Benjamin Botsford ${ }^{1}$, Gustavo Vedana ${ }^{2}$, Leslie Cope ${ }^{3}$, Samuel C. Yiu², Albert S. Jun²

\begin{abstract}
Purpose: To compare the effect of $20 \%$ sulfur hexafluoride $\left(\mathrm{SF}_{6}\right)$ with that of air on graft detachment rates for intraocular tamponade in Descemet membrane endothelial keratoplasty (DMEK).

Methods: Forty-two eyes of patients who underwent DMEK by a single surgeon (A.S.J.) at Wilmer Eye Institute between January 2012 and 2014 were identified 21 received air for intraocular tamponade and the next consecutive 21 received $\mathrm{SF}_{6}$. The main outcome measure was the graft detachment rate; univariate and multivariate analyses were performed.

Results: The graft detachment rate was $67 \%$ in the air group and $19 \%$ in the SF group $(p<0.05)$. No complete graft detachments occurred, and all partial detachments underwent intervention with injection of intraocular air. The percentages of eyes with $20 / 25$ or better vision were not different between the groups (67\% vs $71 \%)$. Univariate analysis showed significantly higher detachment rates with air tamponade $(\mathrm{OR}, 8.50 ; p<0.005)$ and larger donor graft size $(\mathrm{OR}, 14.96 ; p<0.05)$. Multivariate analysis with gas but not graft size included showed that gas was an independent statistically significant predictor of outcome $(O R, 6.65 ; p<0.05)$. When graft size was included as a covariate, gas was no longer a statistically significant predictor of detachment but maintained OR of $7.81(p=0.063)$ similar to the results of univariate and multivariate analyses without graft size.
\end{abstract}

Conclusion: In comparison with air, graft detachment rates for intraocular tamponade in DMEK were significantly reduced by $20 \%$ SF .

Keywords: Descemet membrane; Descemet stripping endothelial keratoplasty/ instrumentation; Sulfur hexafluoride/administration \& dosage; Endotamponade; Visual acuity

\section{RESUMO}

Objetivo: Comparar as taxas de descolamento do botão endotelial com o uso de gás hexafluoreto de enxofre a 20\% (SFG) em relação ao ar para o tamponamento intraocular na ceratoplastia endotelial da membrana de Descemet (DMEK).

Métodos: Quarentae dois olhos foram operados com a técnica de DMEK porum único cirurgião (A.S.J.) no Wilmer Eye Institute entre janeiro de 2012 a 2014. Os primeiros 21 olhos receberam ar para o tamponamento intraocular após o enxerto do botão endotelial e os 21 olhos seguintes receberam SF6. O desfecho primário medido foi a taxa de descolamento do botão endotelial por análise univariada e multivariada.

Resultados: A taxa de descolamento do botão endotelial foi de $67 \%$ no grupo que recebeu ar vs $19 \%$ no grupo que recebeu SF $6(p<0,05)$. Não houve nenhum descolamento total de botão e todos os parciais foram tratados com injeção de ar intraocular. Não houve diferença estatística significativa entre os grupos em relação a AV de 20/25 ou melhor (67\% vs $71 \%$ ). A análise univariada demonstrou maior taxa de descolamento com o tamponamento por ar intraocular $(O R 8,50, p<0,005)$ e com botóes doadores maiores $(O R \quad 14,96, p<0,05)$. Na análise multivariada, incluindo gás, mas não o tamanho do botão doador, o tipo de gás usado permaneceu sendo um fator preditivo independente e estatisticamente significativo para o desfecho primário, com OR de $6,65(p<0,05)$. Porém, quando o tamanho do botão doador foi incluso como covariável, o gás perdeu a sua significância como preditor de descolamento, mantendo o OR de 7,81 ( $p=0,063)$, semelhante as análises univariada e multivariada excluindo 0 tamanho do botão doador.

Conclusão: $O$ uso de gás hexafluoreto de enxofre a 20\% (SF6) para o tamponamento intraocular reduz a taxa de descolamento do botão endotelial quando comparado ao uso de ar no DMEK.

Descritores: Lâmina limitante posterior; Ceratoplastia endotelial com remoção da lâmina limitante posterior/instrumentação; Hexafluoreto de enxofre/administração \& dosagem; Tamponamento interno; Acuidade visual

\section{INTRODUCTION}

Descemet membrane endothelial keratoplasty (DMEK) is an attractive alternative to corneal transplantation for patients with endothelial dysfunction. The procedure involves transplantation of a graft consisting of donor endothelium and Descemet membrane (DM) that replaces the host endothelium and DM. This procedure offers certain advantages over Descemet stripping (automated) endothelial keratoplasty (DS(A)EK) in which the graft includes portions of stromal tissue that may distort the corneal architecture, produce more higher-order aberrations, and provide more immunogenic tissue that could possibly precipitate graft rejection ${ }^{(1-5)}$. Although DMEK has been shown to have quicker and more pronounced visual rehabilitation than DSEK ${ }^{(1)}$, the different techniques and learning curve of DMEK have limited widespread adoption of this approach.

One of the most important challenges facing DMEK is preventing postoperative graft detachment, which is the most frequent complication of the procedure. Detachment rates reported in the literature vary, with one recent multicenter study reporting rates of $34.6 \%{ }^{(6)}$.
Submitted for publication: January 18,2016

Accepted for publication: April 14, 2016

Tufts University School of Medicine, Boston, MA, United States.

Wilmer Eye Institute, Johns Hopkins Medical Institutions, Baltimore, MD, United States.

Oncology Center-Biostatistics/Bioinformatics, Johns Hopkins University, Baltimore, Maryland, United States.
Funding: This study was supported by grants from the J. Willard and Alice S. Marriott Foundation, Edward Colburn, Lorraine Collins, Richard Dianich, Mary Finegan, Barbara and Peter Freeman, Stanley Friedler, MD, Ida Jeffries, Herbert Kasoff, Diane Kemker, James Lamson, Jean Mattison, Florenz Ourisman, Lee Silverman, and Norman Tunkel, PhD (all to ASJ).

Disclosure of potential conflicts of interest: None of the authors have any potential conflict of interest to disclose.

Corresponding author: Albert S. Jun. 400 N. Broadway, Smith 5011 - Wilmer Eye Institute, Johns Hopkins Medical Institutions - Baltimore, MD 21231 - USA - E-mail: aljun@jhmi.edu

Approved by the following research ethics committee: Johns Hopkins Medicine Institutional Review Board (\# IRB00061877). 
These detachments may necessitate postoperative intervention involving reinjection of intraocular air.

Although some surgeons use air for tamponade during the procedure, longer-acting inert gases, such as sulfur hexafluoride $\left(\mathrm{SF}_{6}\right)$, have been explored for this application recently. SF has a higher buoyancy and a longer half-life than those of air( ${ }^{(7)}$, which possibly provides advantages for maintaining graft attachment postoperatively. A recent study of 44 patients who underwent DSEK compared SF with air for graft attachment and noted that, although patients who received air had five graft detachments, there were no detachments reported in the group that received $\mathrm{SF}_{6}{ }_{6}^{(8)}$. Additionally, Guell et al., recently demonstrated reduced detachment rates with $\mathrm{SF}_{6}$ from those with air in their series, and no effect on corneal endothelial cell counts was observed ${ }^{(9)}$. In the present study, we compared graft detachment rates between $\mathrm{SF}_{6}$ and air for intraocular tamponade in DMEK.

\section{METHODS}

A retrospective chart review was performed to evaluate patients who underwent DMEK by a single surgeon (A.S.J.) at the Wilmer Eye Institute of Johns Hopkins Hospital between January 2012 and December 2014. Forty-two eyes were identified; 21 received air for intraocular tamponade and 21 received $\mathrm{SF}_{6}$. Approval from the Institutional Review Board of Johns Hopkins University was obtained, and the study was conducted in concordance with the ethical principles established in the Declaration of Helsinki.

Data on patient demographics, preoperative and postoperative intraocular pressure (IOP), best spectacle corrected visual acuity (BSCVA), graft detachment, and donor tissue were collected from the patients' operative and follow-up notes and from tissue bank information. BSCVA was measured using the Snellen chart, and IOP was measured using Goldmann applanation tonometry. The indication for all operations was bullous keratopathy caused by Fuchs' endothelial dystrophy.

\section{SURGICAL PROCEDURE}

Operations were performed under sub-Tenon anesthesia by a single surgeon (A.S.J.). Initial steps of the procedure were performed by making a $2.75-\mathrm{mm}$ clear corneal keratome incision and included scoring of the DM at the same size as the planned graft, removal of the DM, and scraping of the peripheral recipient stromal bed. All patients underwent an intraoperative inferior peripheral iridectomy. In 32 of the 42 cases, combined phacoemulsification with intraocular lens $(\mathrm{IOL})$ implantation was performed before any steps of the DMEK procedure.

Sterile $20 \% \mathrm{SF}_{6}$ gas mixed with air was prepared as follows: $100 \%$ filtered $\mathrm{SF}_{6}$ gas was drawn up from the tank into a syringe and diluted to $20 \%$ with filtered air. Using a stop-cock, the $20 \% \mathrm{SF}_{6}$ gas was distributed into 1-cc syringes with capped 30-gauge intraocular cannulas.

Preparation and insertion of donor tissue was performed as previously described ${ }^{(10)}$. In brief, standard intravenous tubing (part number MX451FL; Smiths Medical, Dublin, OH) was cut approximately 2 inches from the Luer lock and attached to an Alcon B IOL cartridge (Alcon, Fort Worth, TX). Trephination was performed on pre-dissected DMEK donor tissue obtained from Lions VisionGift (Portland, OR) with sizes ranging from 7.75 to $8.5 \mathrm{~mm}$ depending on the recipient's corneal size. Donor tissue was stained with trypan blue and placed into the IOL cartridge. After the graft was inserted and unfolded, the eye was completely filled with either air or a $20 \%$ SF $_{6}$ mixture. Following a 10-minute waiting period, a small amount of gas was released to reduce the IOP to approximately $10-20 \mathrm{mmHg}$ by palpation. The patient was then discharged home and instructed to remain in the supine position as follows: for air, the supine period was continuous until 6 pm on postoperative day 2 and included 10-minute upright periods hourly while awake and every 2 hours overnight on the night of surgery only; for $\mathrm{SF}_{6^{\prime}}$ the supine period was continuous for the day of surgery and postoperative day 1 and included 10-minute upright periods hourly while awake and every 2-3 hours overnight on the night of surgery and the next night. For postoperative days 2 and 3, 2 hours of supine positioning were interspersed with 1 hour of upright light activity and no overnight positioning, and for postoperative days 4 and 5, 2 hours of supine positioning were interspersed with 2 hours of upright light activity and no overnight positioning. Starting at the postoperative day 1 visit, standard postoperative topical corticosteroids and antibiotics were applied to the operated eye.

\section{FolLow-up}

The patients' follow-up information was obtained at 1 day, 1 week, and 1 month postoperatively. BSCVA measurements postsurgically were taken from approximately 6 months after intervention (range, 4-7 months). No complete graft detachments occurred, and all partial detachments identified in data collection underwent intervention with reinjection of intraocular air.

\section{Statistical analyses}

Analyses using the two-tailed Student's t-test and chi-squared tests were performed. Additionally, we performed univariate and multivariate analyses to evaluate the association between measured variables and graft detachment rates. Analyses were performed in the $R$ statistical computing environment using the $g \operatorname{lm}()$ function with the option, "family='binomial."' $P<0.05$ was considered to indicate statistical significance.

\section{RESULTS}

Forty-two eyes were included; 21 received air and the next 21 consecutive eyes received $\mathrm{SF}_{6}$ for intraocular tamponade. Table 1 summarizes the baseline characteristics for each group. The preoperative BSCVA values were significantly different between the two groups (Group 1 (air): logMAR, $0.33 \pm 0.15$; Group 2 (SF ${ }_{6}$ ): logMAR, $0.48 \pm 0.21 \quad(p=0.014)$, with no significant differences in the other preoperative measures.

For other ocular comorbidities, one patient in group 1 had diabetic macular edema, one patient in group 1 had epiretinal membranes in both eyes, one in group 1 had a history of optic neuritis, two patients in group 2 were glaucoma suspects, and one patient in group 2 had mild amblyopia OS.

Table 1. Baseline characteristics

\begin{tabular}{|c|c|c|}
\hline & Group 1 (air) & Group $2\left(\mathrm{SF}_{6}\right)$ \\
\hline № of eyes/patients & $21 / 17$ & $21 / 16$ \\
\hline \multicolumn{3}{|l|}{ Age (years) } \\
\hline$($ Mean \pm SD) & $62.90 \pm 7.50$ & $63.50 \pm 5.60$ \\
\hline \multicolumn{3}{|l|}{ Sex } \\
\hline (\% male) & $29 \%$ & $25 \%$ \\
\hline (\% female) & $71 \%$ & $75 \%$ \\
\hline \multicolumn{3}{|c|}{ Preoperative BSCVA (logMAR) } \\
\hline$($ Mean \pm SD) & $0.33 \pm 0.15$ & $0.48 \pm 0.21^{+}$ \\
\hline \multicolumn{3}{|l|}{ Donor age } \\
\hline$($ Mean \pm SD) & $68.70 \pm 4.80$ & $65.70 \pm 5.80$ \\
\hline \multicolumn{3}{|c|}{ Donor endothelial cell count } \\
\hline$($ Mean \pm SD) & $2852 \pm 239$ & $2808 \pm 401$ \\
\hline \multicolumn{3}{|c|}{ Death to transplant (days) } \\
\hline$($ Mean \pm SD) & $4.30 \pm 1.10$ & $4.60 \pm 1.60$ \\
\hline
\end{tabular}




\section{Operative characteristics}

Table 2 summarizes operative measurements and information. Eighty-six percent of the air cases were combined with CE/IOL, and $67 \%$ of the $\mathrm{SF}_{6}$ cases were combined with CE/IOL. There was a significant difference in graft size between the groups (group 1, $8.4 \pm 0.2 \mathrm{~mm}$; group 2, $8.1 \pm 0.2 \mathrm{~mm}(p=0.000010)$.

\section{Visual OUTCOMES}

The mean change in BSCVA was $-0.24 \pm 0.19$ inches in group 1 and $-0.39 \pm 0.17$ inches in group $2(p=0.011)$. However, there was no significant difference in the percentages of eyes with 20/25 or better BSCVA between the groups (67\% vs. $71 \%)$.

\section{Graft detachment Rate}

No complete graft detachments occurred. Intervention involving reinjection of intraocular air occurred in 67\% of the eyes in group 1 (air) and in 19\% in group $2\left(\mathrm{SF}_{6}\right)(p=0.0020)$. All cases of partial detachment were deemed appropriate for reinjection of air.

\section{Other complications}

There was one case of pupillary block in group 1 on postoperative day 1 and one occurrence in group 2 on postoperative day 2 . There was no significant difference in IOPs on the first day between the groups (Table 2). No graft rejections or failures were noted.

In univariate analysis (Table 3), the gas used was the most significant factor predicting graft detachment (odds ratio, 8.50; $p=0.0031$ ). Graft size was also significant (odds ratio, 14.96; $p=0.043$ ).

Table 2. Surgical outcomes

\begin{tabular}{lccc}
\hline & $\begin{array}{c}\text { Group 1 } \\
\text { (air) }\end{array}$ & $\begin{array}{c}\text { Group 2 } \\
\text { (SF } \mathbf{6}_{\mathbf{6}}\end{array}$ & $\begin{array}{c}\boldsymbol{p} \text {-value } \\
\text { (Group 1 vs. Group 2) }\end{array}$ \\
\hline $\begin{array}{c}\text { Combined with CE/IOL } \\
\text { (\%) }\end{array}$ & 86 & 67 & 0.150000 \\
$\begin{array}{c}\text { Post-op BSCVA (logMAR) } \\
\text { (Mean } \pm \text { SD) }\end{array}$ & $0.10 \pm 0.12$ & $0.09 \pm 0.10$ & 0.900000 \\
$\begin{array}{l}\text { Graft Size (mm) } \\
\text { (Mean } \pm \text { SD) }\end{array}$ & $8.40 \pm 0.20$ & $8.10 \pm 0.20$ & 0.000010 \\
$\begin{array}{c}\text { Detachment rate } \\
\text { (\%) }\end{array}$ & 67 & 19 & 0.002000 \\
Pre-op IOP & & & \\
(Mean \pm SD) & $13.10 \pm 3.20$ & $14.50 \pm 3.10$ & 0.160000 \\
IOP POD\#1 & & & \\
(Mean \pm SD) & $18.80 \pm 9.50$ & $16.40 \pm 4.00$ & 0.300000 \\
\hline
\end{tabular}

Table 3. Univariate analysis of effect on graft detachment rate

\begin{tabular}{lccrc}
\hline & Odds ratio & LCB $^{+}$ & $\mathbf{U C B}^{\mathbf{}}$ & $\boldsymbol{p}$-value \\
\hline Patient age & 0.98 & 0.89 & 1.08 & 0.6900 \\
Patient sex & 1.50 & 0.39 & 5.77 & 0.5600 \\
IOP Pre-op & 0.81 & 0.65 & 1.00 & 0.0560 \\
Pre-op BSCVA & 0.07 & 0.00 & 2.46 & 0.1400 \\
Change VA & 9.12 & 0.30 & 278.31 & 0.2000 \\
Gas used & 8.50 & 2.06 & 35.08 & 0.0031 \\
Graft size (mm) & 14.96 & 1.09 & 205.56 & 0.0430 \\
Death to transplant (days) & 1.02 & 0.66 & 1.59 & 0.9200 \\
Pre-op endothelial cell density & 1.00 & 1.00 & 1.00 & 0.8100 \\
\hline
\end{tabular}

$+L C B=$ lower border of $95 \%$ confidence interval; $\neq U C B=$ upper border of $95 \%$ confidence interval.
In multivariate analysis (Table 4) with gas included but not graft size, gas remained an independent statistically significant predictor of detachment (air: OR, 6.65; $p=0.020$ ). When graft size was included as a covariate, gas was no longer a statistically significant predictor of detachment but maintained OR of $7.81(p=0.063)$, similar to results of univariate and multivariate analyses without graft size. No other factor in this analysis was significant.

\section{DISCUSSION}

In this study, we compared the outcomes of 42 eyes that underwent DMEK at our institution, 21 with 20\% SF and 21 with 100\% air used for intraocular tamponade, and focused on detachment and intervention rates. We demonstrated a lower detachment rate when SF was used, and no significant differences in other outcome measures were observed.

Complication rates with DMEK have improved over the years with refinements in surgical technique and increased surgical experience. Graft detachment rates have dramatically improved. An important criterion to consider, however, is the surgeon's determination of which detachments require intervention. A recent series by Terry using SF, for DMEK demonstrated a $6 \%$ graft rebubbling rate, although a $47 \%$ graft detachment rate as measured by optical coherence tomography $(\mathrm{OCT})$ was reported ${ }^{(11)}$. Their rebubbling criteria were separation of donor Descemet membrane causing central corneal edema affecting vision and/or evidence of progressive separation of the graft over successive visits. Guell et al. noticed a similar rebubbling rate but stated that they also had detachments that did not fit their criteria for rebubbling ${ }^{(9)}$. In our study, all of the partial graft detachments were determined to fit our criteria for rebubbling, which included central corneal edema affecting vision. There are limited data on whether more aggressive intervention is necessary or beneficial to long-term vision recovery, and currently the decision to intervene is at the surgeon's discretion.

In our experience, the incorporation of SF coincided with the transition to smaller trephine size $(8.0 \mathrm{~mm})$. Both smaller trephine size and use of SF correlated with reduced risk of detachment in the univariate analysis (Table 3). Multivariate analysis with both variables included was, therefore, partially confounded. However, comparison of the detachment rates between eyes with the same graft size but that had received $\mathrm{SF}_{6}$ or air suggests a benefit for the former. For example, $8.5-\mathrm{mm}$ grafts showed detachments rates of $68 \%$ for group $1(13 / 19)$ and $20 \%$ for group $2(1 / 5)$. For graft sizes of $\leq 8.0 \mathrm{~mm}$, the detachment rates were 50\% for group $1(1 / 2)$ and 19\% for group 2 (3/16). However, the coinciding changes in smaller graft size from 8.5 to $8.0 \mathrm{~mm}$ with the introduction of $\mathrm{SF}_{6}$ led to only two eyes in our series receiving both $8.0-\mathrm{mm}$ graft size and air, which made a more robust analysis difficult. The high odds ratio for reduced detachment rate with $\mathrm{SF}_{6}$ use and the significance from univariate and multivariate analyses with graft size removed strongly suggest that the gas used is a significant factor affecting detachment rate. Additionally, the gas

Table 4. Effect of air on detachment rate determined by multivariate analysis with and without graft size included

\begin{tabular}{lcccc}
\hline & Odds ratio & LCB $^{+}$ & UCB $^{\ddagger}$ & P-value \\
\hline $\begin{array}{l}\text { Graft size excluded } \\
\text { Gas used (Air) }\end{array}$ & 6.65 & 1.35 & 32.83 & 0.020 \\
Graft Size Included & & & & \\
Gas used (Air) & 7.81 & 0.90 & 67.95 & 0.063 \\
Graft size & 0.60 & 0.01 & 60.66 & 0.830 \\
\hline
\end{tabular}

$+\angle C B=$ lower border of $95 \%$ confidence interval; $\neq U C B=$ upper border of $95 \%$ confidence interval. No other factors from univariate analysis were statistically significant on multivariate analysis. 
used had a much more statistically significant effect than did graft size when both were included in the multivariate model. However, because our study design was retrospective, and changes in graft size coincided with the change from air to $\mathrm{SF}_{6}$, our analysis could not determine the relative contribution of these two factors.

An additional concern with use of $\mathrm{SF}_{6}$ is potential toxicity to the corneal endothelium ${ }^{(12)}$. Although the gas is thought to be inert, increased buoyancy and longevity of the gas may have mechanical effects on the endothelial surface ${ }^{(13)}$. A recent in vitro study, however, found no significant difference between SF and air on endothelial cell counts or toxicity of corneal endothelial cell $s^{(14)}$. Additionally, Guell et al. found no difference in endothelial cell counts between use of SF ${ }_{6}$ or air $\leq 3$ years after DMEK ${ }^{(9)}$.

One weakness of our study was that the $\mathrm{SF}_{6}$ procedures followed the air procedures chronologically because detachment rates have been found to diminish with experience of the surgeon ${ }^{(15)}$. However, the reduction in detachment rates from the first 21 to the next 21 consecutive eyes was dramatic, and detachment rates were equivalent between those in the first half of air cases and those in the second half. Although technical improvement of the surgeon may account for some of this difference, SF was found to have a substantial impact on maintaining graft adherence and preventing graft detachment post-surgery without any significant differences in other outcome measures in our study. Randomized prospective studies could further address this important question.

\section{REFERENCES}

1. Goldich Y, Showail M, Avni-Zauberman N, Perez M, Ulate R, Elbaz U, et al. Contralateral eye comparison of descemet membrane endothelial keratoplasty and descemet stripping automated endothelial keratoplasty. Am J Ophthalmol. 2015;159(1):155-9 e1.

2. Guerra FP, Anshu A, Price MO, Giebel AW, Price FW. Descemet's membrane endothelial keratoplasty: prospective study of 1-year visual outcomes, graft survival, and endothelial cell loss. Ophthalmology. 2011;118(12):2368-73.
3. Rudolph M, Laaser K, Bachmann BO, Cursiefen C, Epstein D, Kruse FE. Corneal higher-order aberrations after Descemet's membrane endothelial keratoplasty. Ophthalmology. 2012;119(3):528-35.

4. Anshu A, Price MO, Price FW Jr. Risk of corneal transplant rejection significantly reduced with Descemet's membrane endothelial keratoplasty. Ophthalmology. 2012; 119(3):536-40

5. Price MO, Giebel AW, Fairchild KM, Price FW Jr. Descemet's membrane endothelial keratoplasty: prospective multicenter study of visual and refractive outcomes and endothelial survival. Ophthalmology. 2009;116(12):2361-8. Comment in: Ophthalmology. 2010;117(7):1459-60; author reply 1460

6. Monnereau C, Quilendrino R, Dapena I, Liarakos VS, Alfonso JF, Arnalich-Montiel F, et al. Multicenter study of descemet membrane endothelial keratoplasty: First case series of 18 surgeons. JAMA Ophthalmology. 2014;132(10):1192-8. Comment in: JAMA Ophthalmol. 2015;133(6):725. JAMA Ophthalmol. 2015;133(6):724-5.

7. Thompson JT. Kinetics of intraocular gases. Disappearance of air, sulfur hexafluoride, and perfluoropropane after pars plana vitrectomy. Arch Ophthalmol. 1989;107(5): 687-91.

8. Acar BT, Muftuoglu O, Acar S. Comparison of sulfur hexafluoride and air for donor attachment in Descemet stripping endothelial keratoplasty in patients with pseudophakic bullous keratopathy. Cornea. 2014;33(3):219-22.

9. Guell JL, Morral M, Gris O, Elies D, Manero F. Comparison of sulfur hexafluoride $20 \%$ versus air tamponade in descemet membrane endothelial keratoplasty. Ophthalmology. 2015:122(9):1757-64

10. Kim EC, Bonfadini G, Todd L, Zhu A, Jun AS. Simple, inexpensive, and effective injector for descemet membrane endothelial keratoplasty. Cornea. 2014;33(6):649-52.

11. Terry MA, Straiko MD, Veldman PB, Talajic JC, VanZyl C, Sales CS, et al. Standardized DMEK technique: reducing complications using prestripped tissue, novel glass injector, and Sulfur Hexafluoride (SF6) Gas. Cornea. 2015;34(8):845-52.

12. Landry H, Aminian A, Hoffart L, Nada O, Bensaoula T, Proulx S, et al. Corneal endothelia toxicity of air and SF6. Invest Ophthalmol Vis Sci. 2011;52(5):2279-86.

13. Green $K$, Cheeks L, Stewart DA, Norman BC. Intraocular gas effects on corneal endothelia permeability. Lens Eye Toxic Res. 1992;9(2):85-91.

14. Schaub F, Simons HG, Roters S, Heindl LM, Kugler W, Bachmann BO, et al. [Influence of $20 \%$ sulfur hexafluoride (SF6) on human corneal endothelial cells: An in vitro study]. Ophthalmologe .2016;113(1):52-7. German.

15. Dapena I, Ham L, Droutsas K, van Dijk K, Moutsouris K, Melles GR. Learning Curve in Descemet's Membrane Endothelial Keratoplasty: First series of 135 consecutive cases. Ophthalmology. 2011;118(11):2147-54.

\title{
8 jornada Paulista de oftalmologia \\ 8a Jornada Paulista de Oftalmologia
}

\author{
30 de março a 1ำ de abril de 2017 \\ Vitória Hotel \\ Campinas - SP \\ Realização: UNESP - UNICAMP - USP - Ribeirão Preto
}

Informações:

Tel.: (11) 5082-3030 / 5084-5284

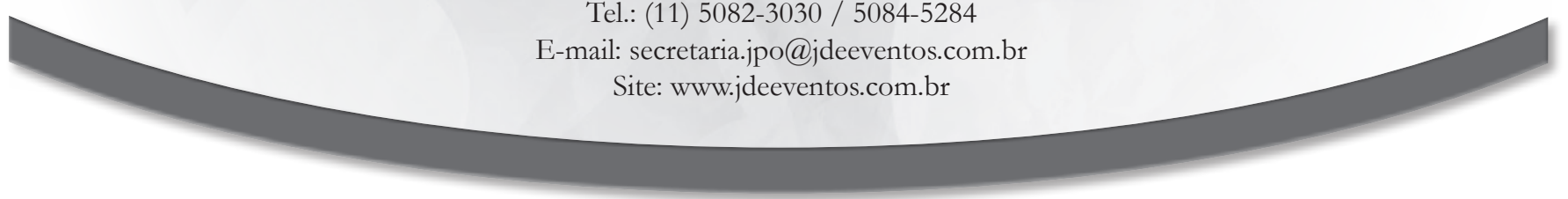

